\title{
The Relationship of Chemistry Teacher Deliberation (MGMP) Activities, and Academic Supervision with Teacher Performance
}

\author{
Panut*, Rustam Effendi, Muhammad Saleh \\ Master Program of Educational Management, Universitas Lambung Mangkurat, Banjarmasin 70123, \\ Indonesia
}

Article history:

Submission December 2019

Revised May 2020

Accepted June 2020

*Corresponding author:

E-mail:panut.cipto@gmail.com

\begin{abstract}
The purpose of this research was to determine the relationship between chemistry Teacher Deliberation (MGMP) activities and academic supervision with performance assessment (PKG). It uses a quantitative approach with descriptive methods and correlation techniques. Data were obtained from a sample of 54 chemistry teachers from all Senior High School in Banjarmasin using a questionnaire that tested for validity and reliability. Data were analyzed to determine the relationship between variables using Pearson product-moment and multiple correlations. The results showed there was a positive relationship between MGMP chemistry activities and performance assessment. There was also a positive relationship between academic supervision and performance assessment, as well as between MGMP activities and academic supervision with performance assessment. There is a need for learning to shift from the teacher to the student center as an implication of adopting the 2013 curriculum.
\end{abstract}

Keywords: Chemistry Teacher Deliberation (MGMP), academic supervision, teacher performance assessment

\section{Introduction}

The teacher is at the center of education and executes vital roles such as teaching guiding, directing, training, giving, assessing, and evaluating students in early childhood, primary, and secondary levels.

Several competencies strongly influence the performance of teachers. According to Normianti et al. (2019), performance refers to an entire effort made to achieve the learning process. A teacher produces high performance depending on the learning management process. This is a very significant factor for school institutions since it relates to teaching.

Performance can be developed through MGMP activities, which involve teacher organization with the primary objective of improving performance to achieve quality education. Additionally, to assess performance, teachers need academic supervision for all activities to be carried out properly, effectively, and efficiently. Academic supervision helps teachers both individually and in groups to improve the quality of education (Sahertian, 2000).

This research examines the relationship between MGMP chemistry activities with teacher performance assessments, academic supervision with performance assessments, and MGMP activities and academic supervision with performance assessments.

MGMP is a teacher organization that aims at uniting the activities of professional members and improve their professionalism (Hasanah, 2012). Its main objective is to improve the professional competence of teachers and enhance the quality of education. In general, it is meant to develop teachers and improve the success of Teaching and Learning Activities (KBM), including the preparation of curriculum, syllabus, semester programs, lesson plans, learning 
methods, media and evaluation tools, and basic materials.

The results of preliminary observations indicate that the academic supervision system prioritizes administrative aspects carried out by chemistry teachers and less attention to the guidance in improving performance. The stated that efforts to improve the quality of education are made through supervision services from school supervisors, principals, and teacher performance. Implementation of academic supervision properly and correctly have an impact on improving teacher performance.

The performance involves efforts to achieve organizational goals such as vision, mission, and strategic plans. It indicates the level of success and failure of the activities in line with specified programs and policies.

In general, performance is the level of success of an employee in completing work. Teacher productivity is the result achieved in carrying out tasks based on skills, experience, sincerity, and use of time. Teacher performance is influenced by several factors, such as principal leadership, environment, climate, motivation, and discipline (Suhaimi \& Wardaniah, 2017).

According to the Ministry of Administrative and Bureaucratic Reform of the Republic of Indonesia (MENPANRB) Regulation number 16 of 2009, Teacher Performance Assessment (PKG) is an assessment of the task items in the promotion of rank, career, and position, carried out by the principal or the assessor team. According to Sahrudin, Usman \& Aslamiah, the results of PKG activities could be used to improve competence, including social, professional, pedagogical, and personality competencies (Rasyidah et al., 2019).

There is a need for aspects that can be assessed from the performance, such as work skills, responsibilities, discipline of cooperation, and quality of work to determine the achievement obtained, the level of ability shown by teachers in working, and how well the work is achieved. A performance indicator is something that can be calculated and quantified, and therefore it is necessary to identify the form of measurement in assessing the results and outcomes of activities (Ulfa et al., 2019). The purpose of performance assessment is to help identify teacher strengths and weaknesses, professional development, career and potential, policymaking, strategies for improvement, selection of assignments, extension services, enhancing of management, provision of information, making plans for sustainable professional development programs, and provides assurance that instructors carry out professional responsibilities.

\section{Material and Methods}

This research is a descriptive study with a quantitative approach. Data analysis using correlation techniques. In this study, 2 independent variables were used, MGMP Chemistry activity, and academic supervision by the principal. Meanwhile, the variable of the performance evaluation or assessment of chemistry teachers.

The sample of this research involved 54 chemistry teachers in all Senior High Schools in Banjarmasin. Data collection used questionnaires for variables X1 and X2, distributed to 54 teachers as respondents, then filled according to the actual situation in each school. The Y variable was taken from the results of the performance assessment of a chemistry teacher that had been conducted by Senior High School principals in Banjarmasin.

The test requirements using the analysis of normality and linearity. Based on the normality test, samples taken from the population could either be normally distributed or not. In case, the test was normal, the statistical calculation results can be generalized to the population. The normality test used SPSS version 20.0 of the Kolmogorov-Smirnov with $\mathrm{p}>0.05$ for normal distribution. For the linearity test, the SPSS program the test for linearity with a significance level of 0.05 (Sugiyono, 2009).

\section{Results and Discussion}

To improve MGMP, teachers need to carry out the Lesson Study regularly. The principal should facilitate, support, and motivates the teacher to conduct a Lesson Study. The implementation of a school-based Lesson Study should include all teachers and encourage be models. In this context, MGMP creates a new culture that helps to build a learning atmosphere. By focusing on collegial principles and 
sharing knowledge and experience, teachers are motivated to improve their professional level. Therefore, each of them collaborates to enhance the quality of the learning process.

With adequate supervision from the principal, the quality of learning improved successfully, primarily when the model used followed process Standards. This condition indirectly increases the ability of students to be creative, innovative, able to solve problems, think critically, and have an entrepreneurial mind. Students form character and have a mindset and freedom of thought. For this reason, they can carry out the development of the ability to be independent, creative, and nationally oriented.

The active involvement of students in the learning process is carried out to achieve an understanding of concepts, not limited to the learning material provided. The teacher is responsible for the quality of planning learning activities.

The obstacles related to teacher competency occur for several reasons and are divided into two parts, internal and external factors. Essentially, internal factors come from within the teacher. Educational people are sometimes not ready to face the rapid development of communication. There are still teachers who have not qualified in carrying out their tasks and obligations scientifically. External factors from outside the teacher include the development of information technology, government policies, and global competition. Teachers are also still reluctant to change and move to follow developments. Information and communication have continued to develop very rapidly since the 90s with the invention of the internet.

The test linearity assumption and normal distribution in this study meet all the set requirements. Therefore, the relationship between variables might use the coefficient correlation. The results of the correlation analysis of chemistry and it shows that there is a significant relationship between these two variables.

From the results of these calculations, the two independent variables, both MGMP chemistry and academic supervision, explain the performance of chemistry teacher in Senior High School in Banjarmasin City. Teacher performance is a comparison between the results for carrying out their primary tasks according to the standards set by the government. Based on the score group of chemistry teacher performance assessment variables, some are included in the high category with a percentage of $75.9 \%$, the moderate at $24.1 \%$, and none is included in the low category. This shows the results of teacher performance assessments conducted by principals or assessor.

Performance-related to the implementation of the learning process for teachers involves planning, implement, evaluate, assess, analyze the results of the assessment, and carry out follow-up results of the assessment. These activities are conducted according to the Minister of National Education Regulation No. 16 of 2007 concerning Academic Qualification Standards and Teacher Competencies. Learning management requires teachers to master 24 competencies, which are grouped into pedagogic, personality, social, and professional categories. In the PKG assessment, the 24 competencies are summarized into 14 , as published by the National Education Standards Agency (BSNP).

The results of this research prove that there is a significant positive relationship between MGMP and academic supervision on teacher performance assessment. These results are in line with various studies in social studies and science junior high schools in Indonesia (Rahmani et al., 2019). The principals feel that the level of effectiveness of the implementation of academic supervision is quite useful. According to the perception of some teachers, the implementation of academic supervision is also quite effective. It involves preparation, application, and evaluation of learning. The implementation of MGMP is a guide for teachers to add information, knowledge, and experience to improve performance. The events organized by the Chemical MGMP can be beneficial for teachers and should be implemented when planning educational activities in school.

The implementation of MGMP chemistry is expected to broaden teachers' insights and knowledge in the preparation and development of Syllabus, Learning Plans, ICT-based teaching materials, discussing difficult essential element, mastering various strategies, 
methods, approaches/media, determining learning resources and minimum completeness criteria (KKM)), learning remedial learning, making test questions for different needs, analyzing learning outcomes, compiling programs and enrichment, and discussing various alternative solutions.

To achieve effective learning activities, the teacher needs help, guidance, or direction from the principal through academic supervision. This involves a series of professional assistance such as giving encouragement, guidance, and direction to improve their ability. Academic supervision focuses on planning, implementing, and evaluating learning. It helps teachers in carrying out their tasks and solving problems in the learning process.

Therefore, in case the teacher plan, implement and evaluate learning appropriately, performance might be achieved according to the objectives. Academic supervision is vital since it improves teacher performance appraisal, which ultimately creates a good learning process and improves student performance.

\section{Conclusion and Recommendation}

Based on the results and discussion, there is a positive relationship between MGMP chemistry activities and teacher performance assessments, between academic supervision by principals and teacher performance assessments, and between chemical MGMP activities and academic supervision.

Based on the results above, several studies can be made. For instance, (1) Senior High School principals need to improve academic supervision in activities including planning, implementation, and assessment, (2) the chemistry teacher needs to maintain MGMP activities, (3) there is need to improve planning, implementation, and evaluation, which improve the results of performance assessment.

\section{Acknowledgment}

Our gratitude and appreciation extend to all parties involved and contributed in completing this research

\section{References}

Hasanah. (2012). Pengembangan profesi guru. Bandung: CV. Pustaka Setia.

Normianti, H., Aslamiah., \& Suhaimi. (2019). Hubungan pemimpin transformasional of utama, guru motivasi, komitmen guru organisasi dengan kinerja sekolah dasar guru di labuan amas selatan, indonesia. European Journal of Education, 5 (11), 123 - 141.

Rasyidah, Saleh, M., \& Hadi, S. (2019). Pengaruh kepemimpinan, iklim kerja dan motivasi terhadap kinerja umum elementary public elementary school guru di district banjarmasin utara. International Journal of Scientific and Development Research (IJSDR),2 (2), 137-140.

Sahertian. (2000). Konsep dasar dan teknik: Supervisi pendidikan. Jakarta: Rineka Cipta.

Sahrudin, Usman, H., \& Aslamiah. (2019). Kepemimpinan transformasional kontribusi dan pengawasan akademik sekolah principal' terhadap kinerja guru public-school in Gambut district, Banjar Kabupaten. International Journal of Scientific and Development Research (IJSDR), 23 (2), 129-132.

Suhaimi, \& Wardaniah. (2017). Hubungan Antara Supervisi Kepala Sekolah Dan Motivasi Berprestasi Dengan kinerja Guru SD Negeri Di Kecamatan Tanjung Kabupaten Tabalong. Prosiding Seminar Nasional PS2DMP ULM, 3 (2), 1-6.

Ulfa, N. M., Mahrita, \& Aslamiah. (2019). Kontribusi kecerdasan dan manajemen kemampuan emosi pada kinerja kepala TK / PAUD di Kabupaten Landasan Ulin. International Journal of Scientific and Development Research (IJSDR), 526 - 529.

Rahmani, M. U., Sulaiman, \& Aslamiah. (2019). Hubungan pengawasan sekolah supervisor dan pengawasan kepala sekolah dengan kinerja guru di sekolah dasar negeri di kecanatan astambul. International Journal of Scientific and Development Research (IJSDR), 2(3), 150 - 154. 